\title{
Arsacid Dynastic Marriages
}

\author{
Edward Dąbrowa
}

Jagiellonian University in Kraków

\begin{abstract}
Dynastic marriages in the Hellenistic world were an important diplomatic tool that provided distinct political benefits to one or both of the parties involved. The Parthian rulers from the Arsacid dynasty also engaged in such unions with other ruling houses. Surviving sources contain information on such marriages with the members of the Seleucid family, the Artaxiad dynasty, which ruled in Armenia, but also ruling houses in Commagene and Media Atropatene. Not all of these links resulted from a bilateral agreement, however; some were the result of imposition of the Arsacids' will. The author attempts to demonstrate the circumstances in which each of the known dynastic marriages of the rulers of Parthia came about, as well as the objectives they hoped to achieve as a result.
\end{abstract}

Key words: Arsacids, Artaxiads, Seleucids, Commagene, Media Atropatene, dynastic marriages.

Among the characteristic political phenomena of the Hellenistic period were marriages between members of the ruling dynasties. ${ }^{1}$ In the world as it was at the time, divided into many states, these marriages were treated as an important political tool. They allowed particular rulers to strengthen their political position both in their own state and elsewhere. Adept arrangement of dynastic marriages was generally beneficial for both sides, enabling them to acquire coalition partners, contributing to the solution of long-lasting conflicts with neighbours over disputed territories, and allowing at least one of the parties to broaden its sphere of influence. However, the status of the two parties was not always equal, and as a result, the stronger partner would often break the union unilaterally if it deemed it not to be beneficial in a specific political situation. The dominance of one of the sides could also lead it to interfere in the internal affairs of its partner in order to force it to act in a conducive way, or to achieve specific goals. A separate issue is the cases of the dynastic marriages which took place not on the basis of a mutual agreement, but coercion. A further significant element of the unions between specific ruling houses was the circumstances that forming them not only justified, but even rendered essential. Owing to the diversity and the sheer number of these situations, each Hellenistic dynastic marriage must be assessed separately, bearing in mind the participating parties, the

\footnotetext{
${ }^{1}$ Cf. Seibert 1967. Many studies of this phenomenon were published by R.D. Sullivan (1978a, b, c).
} 
motives that lay behind it, the circumstances in which it occurred and the objectives it was to serve. By no means should the importance of these factors be underestimated, as they are the key to grasping the essence and shape of the political and cultural relations between the various Hellenistic rulers, as well as their consequences.

There is no doubt that the Arsacid dynasty that ruled the Parthian state, in spite of its Iranian origins, should be treated as belonging to the Hellenistic world. Although the Arsacids distinctly emphasised their Iranian identity, this did not stop them from making use of Hellenistic models in the sphere of culture, politics and ideology, as well as propagating a Philhellene stance towards their Hellenised subjects. The problem is that it is not always clear what the relations of the Parthian rulers with their Hellenistic neighbours looked like. Our knowledge on this subject is full of blanks. The reason for this is above all the paucity of narrative sources - both Greek (despite the extensive Greek historiography of the Hellenistic period, little has survived) and Parthian. Those that we do have only provide a limited insight into the Arsacids' relations with the Seleucids, Bactria, the nomads in Central Asia, Armenia, Media Atropatene, Characene and Elymais. We should also note that our information on these relations is mainly confined to episodes involving mutual armed conflicts. The sources do also contain information that allows us to look at the Arsacids' relations with the rulers of other states from a slightly different perspective - that of the dynastic marriages they entered into. These marriages are an important piece of evidence that shine some light on the objectives and directions of the rulers of Parthia's foreign policy and operating methods.

Nevertheless, it is not possible to obtain a complete picture of the matrimonial alliances of the Arsacids, both because of the low number of sources on the marriages they formed and as a result of the lack of full information on the genealogy of the Parthian ruling house. ${ }^{2}$ As a rule, we do not know the names of the majority of the wives of the Parthian kings, just as we are able to say almost nothing, or only little, on the rulers themselves or their origins. ${ }^{3}$ We know even less about the individual kings' families. Apart from a few exceptions, the names of both their sons and their daughters are unknown, not to speak of which royal bride was their mother.

\section{a) Dynastic marriages of the Arsacids with the Seleucids}

The earliest mentions of the Arsacids showing interest in unions with other dynasties can be found in a description of the campaign by the king of Syria, Demetrius II Nicator, against the Parthians in 139-138 BCE. ${ }^{4}$ Its objective was to liberate Media and Mesopotamia, conquered by Mithridates I (165-131 BCE), from Parthian rule. He probably

2 See Sullivan 1978c, stemma Parthia, between p. 938-938; Assar 2004; 2005.

3 See Huber - Hartmann 2006; Bigwood 2008; Strugnell 2008.

${ }^{4}$ Sachs - Hunger 1996, no. -140A, 'Rev., ll. 7'-9'; cf. also Sachs - Hunger 1996, no. -141F, 'Rev., l. 26'; no. 140A, Obv.', l. 1; 1 Macc 14: 1-3; Josephus, AJ 13.186; Just. 36.1.2-4; Euseb., Chron., p. 120, 16-21 [ed. Karst] (= Porphyry, FGrH 260, F $32.16=$ PNJ 260, F 32); Oros. 5.4.16; cf. App., Syr. 67. See Bouché-Leclercq 1913, 365-366; Will 1982, 407-408, 409; Dąbrowa 1992, 46 -48 (cf. Dąbrowa 2011, 16-19); 1999, 9-16 (=Dąbrowa 2011, 49-57); Mittag 2002, 373-374; Shayegan 2003, 84-87; Ehling 1998a, 227-229; 2008, 184-186. 
captured the first of these lands shortly after $148 \mathrm{BCE},{ }^{5}$ and the second a few years later, in 141 BCE. $^{6}$ We know that Demetrius II and his army invaded Babylonian territory. ${ }^{7}$ Initially enjoying a series of successes, his excessive confidence in his own talents and the errors he made ultimately resulted in the failure of his campaign: the army was crushed, and he and his retinue were enslaved. ${ }^{8}$ Mithridates I used the captured Demetrius II to placate the hostile moods among the Greek residents of Media and Mesopotamia. By showing the royal prisoner to the residents of the cities of these lands, he hoped to encourage them to become reconciled with Parthian rule. ${ }^{9}$ When this humiliating journey for the king of Syria came to an end, his position improved markedly. Mithridates I placed him in one of his palaces in Hyrcania and gave him his own daughter, Rhodogune, in marriage. ${ }^{10}$ The union was accompanied by Mithridates I's promise to restore the Seleucid throne to Demetrius II in future. ${ }^{11}$

The news that reached Demetrius II of the struggle between the pretenders to the throne going on in Syria led him to attempt to flee. Yet he was unsuccessful. Caught in flight, he was sent back to Hyrcania, where he remained under the tightened supervision imposed after Mithridates I's death by his successor, and Rhodogune's brother, Phraates II. He survived the next few years in captivity, and his attitude at this time, according to the Parthian community, suggested that he was resigned to his fate. In fact, he did not give up the intention to return to his homeland. A few years later, he made a renewed attempt to escape, but this too was unsuccessful, and he was again sent back to Hyrcania. Phraates II treated the fugitive leniently. Yet the Parthian king's position was not the result of magnanimity, but political calculation. According to Justin, he intended to use Demetrius II to rule over Syria. ${ }^{12}$ Phraates II planned to pitch him against his brother, Antiochus VII Sidetes, whose aggressive policy with the aim of rebuilding the might of the Seleucids aroused his concern. Antiochus VII was also well aware of the effects of any involvement of the Parthians in Syrian affairs, and, wishing to forestall any Parthian interference in $130 \mathrm{BCE},{ }^{13}$ embarked on a campaign against Phraates II. ${ }^{14}$

5 Cf. Just. 41.6.7; Le Rider 1965, 339-345.

${ }^{6}$ Cf. Will 1982, 408.

${ }^{7}$ Although some ancient authors suggest that the campaign was played out in Media (1 Macc 14:1), the references surviving in cuneiform sources (cf. Sachs - Hunger 1996, no. -137A, 'Rev.', ll. 8'-11') indicate that it was in fact confined to the area of Mesopotamia: Shayegan 2003, 86-87.

81 Macc 14: 3; Pomp. Trogus, prol. 38; Athen., Deipn. 4.153a (= Poseidonios, FGrH 87, F 32 = Edelstein - Kidd 1989, frg. 64 = BNJ 87, F 12); Just. 36.1.5; 38.9.2; 39.1.1-2; App., Syr. 67.

9 Sachs - Hunger 1996, no. -137A, 'Rev.', ll. 10'-11' (cf. Del Monte 1997, 110-111); Just. 36.1.5.

10 Just. 36.1.6; 38.9; App., Syr. 67-68.

11 Just. 38.9.3.

12 Just. 38.9.10; Nabel 2017, 32. Regarding Justin and his interpretation, cf. Mittag 2002, 377-389.

13 Information contained in cuneiform documents (Shayegan 2003, 90-91) justifies the assumption that the beginning of Antiochus VII's expedition took place in $130 \mathrm{BCE}$, and not $131 \mathrm{BCE}$, as was widely assumed based on the sources of Greek and Latin authors; cf. Fischer 1970, 35-48.

14 Diodorus 34/35.15-17; Jos. AJ 13.250-253; Just. 38.10.1-6; App. Syr. 68; Euseb., Chron., p. 120, $33-$ 121, 18 [ed. Karst] (= Porphyry, FGrH 260, F 32.19-20 = BNJ 260, F 32). According to Diodorus (34/35.15), Antiochus VII demanded that Phraates II give up Demetrius II, return all the territories conquered by the Parthians at the expense of the Seleucids, and pay the outstanding tribute. For more on the subject of the expedition, see Fischer 1970; Bouché-Leclercq 1913, 379-384; Will 1982, 413-415; Dąbrowa 1992, 48-50 (cf. Dąbrowa 2011, 19-20); Ehling 1998b, 141-142; Shayegan 2003, 90-92; Ehling 2008, 200-205. 
Similarly to the case of Demetrius II's earlier expedition, the beginning of the campaign was successful for the Syrian king, as he gained a significant advantage over his rival. Among the results of this was the withdrawal of certain vassal rulers from the Parthians. Finding himself in an unfavourable position, Phraates II decided to undertake diversionary actions in Syria, hoping to force Antiochus VII to turn back. He entrusted Demetrius II with their realisation, surrendering a corps of his own men to his leadership. ${ }^{15}$ Antiochus VII's excessive confidence, and the numerous mistakes he made in military art, resulted in loss of support of the local population in the captured territories, as they turned against him. The changing moods of the population enabled the king of Parthia to crush the Syrian forces. ${ }^{16}$ In one of the final battles that decided upon the fate of the expedition, Antiochus VII was killed. ${ }^{17}$ The rapid end to the war meant that the diversionary operation in Syria no longer made sense, and Phraates II decided to cancel it. He no doubt realised that in this situation Demetrius II's actions could bring him more problems than advantages. These concerns proved to be grounded. Before Phraates II's envoys could reach Demetrius II, he had already managed to cross the border of Syria. As soon as he arrived in his homeland, he set about fighting to regain the throne lost years before. ${ }^{18}$ As a result, the Parthian ruler's political plans, which had been tied to him, went up in smoke. ${ }^{19}$

Even if this was the case, Phraates II soon found a solution that could potentially assure him considerable political capital in the future. In the conquered camp of Antiochus VII, he found other members of the Seleucid family who had accompanied him in the campaign, including Laodice, the daughter of Demetrius II. ${ }^{20}$ For the Parthian king, this was a very valuable capture, as he could use her in operations against her father. Laodice's charms apparently soon led the king of Parthia to marry her. ${ }^{21}$ It is hard to say for sure whether this union was dictated solely by the feelings (as Justin suggests) that the ruler ignited, or rather by political calculation. The version with the passionate feelings by no means precludes the other eventuality. In a situation in which Demetrius II had escaped the clutches of Phraates II, the marriage to Laodice gave him the chance to get involved in Syrian affairs under the pretext of defending his wife's interests. In fact, he had several more such pretexts: they also included protecting the rights of the children of Demetrius II, born from his relationship with Rhodogune, to the Syrian throne,

15 Just. 38.10.7; App. Syr. 68.

${ }_{16}$ Pomp. Trogus, prol. 38; Diodorus 34/35.16; 17.2; Just. 38.10.8-10.

${ }_{17}$ Pomp. Trogus, prol. 39; Just. 38.10.9; 39.1.1; Jos. AJ 13.253. According to Appian (Syr. 68), Antiochus VII committed suicide.

${ }_{18}^{18}$ Pomp. Trogus, prol. 39; Just. 38.10.11; 39.1.1; Jos. AJ 13.253; Ehling 1998b, 144-147; 2008, $205-$ 212; Nabel 2017, 32.

${ }^{19}$ Cf. Diodorus 34/35.18. R.R. Shayegan's claim (2003, 92-96) that Demetrius II, after reclaiming power in Syria, was a tool in the hands of Phraates II, though attractive, is also speculative, as it is based on rather uncertain information. Some scholars believe that the Parthian bondage contributed to Demetrius II taking on some of the customs of the Arsacid court, giving as evidence the iconography of the coins he minted during the second period of his rule; cf. Ehling 1998b, 142-144; 2008, 205-208. However, not everyone shares this view; cf. Mittag 2002, 389-399.

${ }^{20}$ Just. 38.10.10; cf. Huber - Hartmann 2006, 500.

${ }^{21}$ According to Justin (28.10.10), the marriage took place soon after the death of Antiochus VII: cui Phrahates exequias regio more fecie filiamque Demetrii, quam secum Antiochus adduxerat, raptus amore virginis uxorem duxit. 
or potentially making use of another member of the Syrian ruling family, who was also supposedly in his hands. ${ }^{22}$

It is unclear whether Phraates II or his successors, at any point and in any way, exploited the aforementioned dynastic marriages with the members of the Seleucid family or their progeny to interfere in the affairs of Syria. Given the paucity of historical sources available, however, this possibility certainly cannot be ruled out. The sources also fail to mention any of the later rulers of Parthia forming any further dynastic union with the Seleucids.

\section{b) Dynastic marriages of the Arsacids with the Artaxiads}

Information on dynastic marriages between the Arsacids and the Artaxiad dynasty that ruled over Armenia dates from several decades later. One of the parchment documents found in Avroman ${ }^{23}$ issued during the reign of a Parthian ruler named Mithridates, ${ }^{24}$ and dated to $87 \mathrm{BCE}$, also mentions his wives. ${ }^{25}$ One of them, named Aryzate, also known as Automa, is notable, as the document makes it clear that she was the daughter of the king of Armena, Tigranes II the Great. ${ }^{26}$ His presence at the side of the king of Parthia clearly suggests close links between the two dynasties. These date to the times of the rule of Mithridates II (c. 121-91), who in around 111/110 was successful, after several attempts, in subordinating the ruler of Armenia, Artavasdes I (121-96 BCE), uncle

${ }^{22}$ Certain scholars, citing references in the works of Athenaeus (Deipn. 4.153a), which he took from Poseidonios (FGrH 87 F 32 = Edelstein - Kidd 1989, frg. 64) and Eusebius (Chron., p. 121, 5-8 [ed. Karst] = Porphyry, FGrH 260, F $32.20=B N J$ 260, F 32), argue that the son of Demetrius II, Seleucus (V), fell into the hands of Phraates II (Bouché-Leclercq 1913, 383-384; 1914, 599-600; cf. this identification was questioned by Thomas Fischer $(1970,49-54))$, while others believe that it was also Antiochus VII, with the same name (cf. Nabel 2017, 27 (tab. 2.1), 32). In fact, the Seleucus and his fortunes mentioned in the cited fragments correspond to those experienced by Demetrius II after the lost war, and it is therefore with him that we should identify the Seleucus mentioned in these sources (cf. K. Dowden, commentary ad Poseidonios, BNJ 87 F 12). The arguments in favour of this view: Edelstein - Kidd 1988, 303-304; cf. Shayegan 2003, 95. There is no lack of suggestions that this Seleucus was in fact the son of Antiochus VII (Shayegan 2003, 95-96). Yet the arguments upon which this identification is based are too tenuous to be acknowledged as likely.

${ }^{23}$ See Minns 1915, 22-65; Luther 2018, 155-156.

${ }^{24}$ Until recently, this ruler was generally identified as Mithridates II, as Gotarzes I or Orodes I, see Luther 2018, 157-159. Based on cuneiform and numismatic sources, we know that he died in 91 BCE: Sachs Hunger 1996, no. -90, 'Obv., l. 31'; Del Monte 1997, 169-170; Assar 2006a, 146-147; 2006b, 52. The ruler mentioned in the document from Avroman is therefore his son, Mithridates III (87-80 BCE), cf. Assar 2005, 67-75. This identification explains why the content of the document contains a description of Tigranes II as 'Basileus Megas'. Recently a new hypothesis based on argument that the Avroman documents were dated not according to the Seleucid era, but to the Arsacid era. Consequence of it is that the mentioned king Mithridates is in fact Mithridates VI, and the king Tigranes is identified with Tigranes the Younger: Luther 2018, 160-170. In this paper the author follows the generally accepted dating.

${ }_{25}$ Minns 1915, 28: Doc. Ia, $l l .1$ 1-5; Hack1 - Jacobs - Weber 2010, II: 467, no. 1, ll. 1-5.

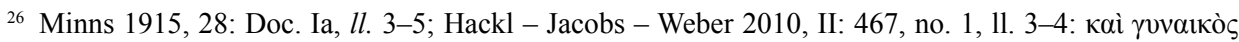

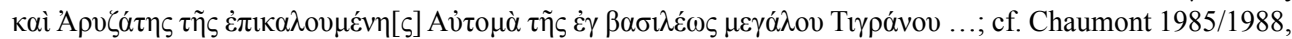
21-23; Sullivan 1978c, 911, 913-914; Huber - Hartmann 2006, 501. 
of Tigranes II, ${ }^{27}$ and who maintained his influence in Armenia for the next two decades. ${ }^{28}$ The stability of these influences assured him a presence in the court as Tigranes' hostage..$^{29}$ He stayed there right up until 96/95 BCE. Then, after his uncle's death, and with the consent of Mithridates II, Tigranes assumed the throne of Armenia. ${ }^{30}$ We can assume that the marriage of the son of the Parthian monarch, Mithridates II, with the daughter of Tigranes took place shortly before he left the Parthian capital. Mithridates II presumably treated her as a guarantee of the loyalty of the new ruler of Armenia. ${ }^{31}$ This hypothesis is supported by the fact that until his father-in-law's death, his relations with the Parthian state were in order. They changed significantly only in the time of Mithridates II's successors, when Tigranes exploited the disputes between pretenders to the Arsacid throne to launch an offensive policy towards his neighbour, whose power had forced him to spend many years in a submissive position. This new policy resulted in the territory of his own country increasing in size, with the lands that Mithridates II had torn away from Armenia being restored. ${ }^{32}$

The next dynastic marriage that we know of between the Arsacids and the Artaxiads took place several decades later. The parties involved were the unnamed daughter of Phraates III and Tigranes the Younger, son of Tigranes II the Great (95-55 BCE), who married in rather unusual circumstances.

In 66 BCE, Pompey assumed command in the war against Mithridates VI and his ally Tigranes II the Great. Important for the success of his military plans was the attitude of the then king of Parthia, Phraates III. If he were to back the coalitionists, this could cause Pompey a number of problems, which he therefore tried to prevent. The Roman leader's fears were not unfounded, since both kings he was fighting against had previously attempted to secure support in the war with Rome of Phraates III's predecessor, Sinatruces. ${ }^{33}$ On the first occasion, around $72 \mathrm{BCE}$, this had been done by Mithridates VI Eupator, ${ }^{34}$ and several years later (c. 69/68), he renewed his request together with Tigranes..$^{35}$ In return for his support, however, Sinatruces demanded the return of lands that Tigranes II had seized several years earlier at the cost of the Arsacid empire. His demand was refused, and the increase in size of the coalition therefore ultimately did not take place. This situation was exploited by Lucullus, who was then in command in the

${ }^{27}$ There are certain contradictions in the source information on the nature of the family relations between Tigranes II and his predecessor. The main subject of debate among scholars is who his predecessor was - his uncle, Artavasdes I, or his father, Tigranes I (App. Syr. 48); see Del Monte 1997, 166-167; Assar 2006a, 142, note 172; Geller - Traina 2013, 448; Kovacs 2016, 11-12. Cf. Chaumont 1985/1988, 17-19.

${ }^{28}$ Sachs - Hunger 1996, no. -110, 'Rev.', l. 14' (cf. Del Monte 1997, 166); Pomp. Trogus, prol. 42; Just. 42.4.1. See Wolski 1980, 255-260; Chaumont 1985/1988, 13-17; Geller - Traina 2013, 448-450; Dąbrowa 2015, 291-292.

${ }^{29}$ Strabo 11.14.15 (C 532); Geller - Traina 2013, 450.

${ }^{30}$ Sachs - Hunger 1996, no. -95A, ll. 9'-12'; no. -95C, 'Obv.', ll. 5'-7'; no. -95D, 'Flake', l. 11' (cf. Del Monte 1997, 165-166); Strabo 11.14.15 (C 532); Just. 38.3.1; Geller - Traina 2013, 450-452.

${ }^{31}$ Cf. Chaumont 1985/1988, 22.

${ }^{32}$ Cf. Strabo 11.14.15 (C 532); Just. 38.3.1. For the problems with identifying some of these territories, see Minns 1915, 41-42; Wolski 1980, 260; Dąbrowa 1983, 18-19; Chaumont 1985/1988, 23-25; Geller Traina 2013, 451.

${ }_{33}$ Memnon, $F G r H$ F 22.4.

${ }^{34}$ Memnon, FGrH F 29.6.

${ }^{35}$ Plut. Luc. 30.1; App. Mithr. 87; Dio 36.1.1-2.3. 
war in the East. He began talks with Sinatruces, in order to distract him from the ongoing conflict for as long as possible. ${ }^{36}$ Although these talks did not lead to an agreement, fortunately for Lucullus, Sinatruces remained neutral. Pompey found himself in the same situation as Lucullus just before leaving the position of commander, with the difference that his partner on the Parthian side was Phraates III. But whereas Lucullus wanted to deceive Sinatruces with discussions not containing concrete proposals, Pompey treated Phraates II much more seriously, proposing a friendship treaty and Roman assent for his capture of the regions of northern Mesopotamia lost to Armenia. Attractive as this offer was, for reasons unclear to us, the king of Parthia delayed his response. This was probably because he did not intend to become only a passive observer of the events playing out close to the borders of his state, but he also wished to avoid provoking the Roman commander into hostile actions by giving away his true intentions too early. Another reason for his slow response to the Roman proposals might have been a much more attractive prospect that opened up to him. As a result, he could gain much more than what the Roman commander was offering him. ${ }^{37}$

Tigranes the Younger was one of three sons of the ruler of Armenia, the two others having been killed by their father as a result of his fears of losing power. ${ }^{38}$ Although Tigranes the Younger was appointed his heir, conflict ensued between father and son, which then led to civil war. Defeated by his father, the son took refuge in the court of Phraates III. The Parthian king agreed to help him in exchange for marrying his daughter. ${ }^{39}$ This marriage handed Phraates III the opportunity for involvement in the affairs of Armenia, whose ruler became an awkward neighbour for him, as well as the chance to engineer a situation to hamper Pompey's activities that endangered Parthian interests. ${ }^{40}$ Based on the context of the events, we can date the marriage of Tigranes the Younger to the daughter of Phraates III to around 66/65 BCE.

Phraates III took his commitments towards his son-in-law seriously, providing him with military support in operations in Armenia, and even involving himself personally until the moment when the campaign, after its first successes, lost its impetus as a result of the need to capture the fortresses defended by garrison loyal to Tigranes II. At this time, Phraates III abandoned his son-in-law, but provided him with the use of some Parthian units. The next phase of fighting was no longer so successful for Tigranes the Younger. Unable to defeat his father, he fought at the side of Pompey, hoping in this way to gain the crown from the Romans. ${ }^{41}$ Yet he was not successful in this objective. When Tigranes II surrendered to Pompey and retained power, Tigranes the Younger, disappointed at Pompey's position, provoked a conflict which would dash all his political hopes. He was imprisoned, and then sent to Rome. ${ }^{42}$ Although Phraates III intervened to Pompey with regard to freeing him, and demanded that the Euphrates be recognised as

${ }^{36}$ According to Memnon ( $F G r H F$ 38.8), Tigranes II did not approach the Parthian king with a request for joint action, but did demand the return of Mesopotamia, Adiabene and the Great Valleys.

37 See Debevoise 1938, 70-75; Dąbrowa 1983, 24-26.

38 Appian, Mithr. 104.

39 Plut. Pomp. 33.6; Appian, Mithr. 104; Dio Cassius 36.51.1; 37.6.4.

${ }^{40}$ Cf. Appian, Mithr. 105.

41 Plut. Pomp. 33.1-2.

42 Plut. Pomp. 33.1-6; Appian, Mithr. 104-105; Dio Cassius 36.51.1-53.6. 
the Roman-Parthian border, little came from his efforts. At the point when the outcome of the war in Armenia was clear, after Tigranes II had surrendered to Pompey in $65 \mathrm{BCE}$, the Roman commander had nothing to fear from Phraates III, and moreover, made it clear that he was even prepared for a military confrontation with him. ${ }^{43}$

It appears that the failure of Phraates III's Armenian plans did not persuade the Arsacids to change their approach towards Armenia. They again set about strengthening their influences there, probably after the death of Tigranes II, when Artavasdes II (55-34 BCE) ascended the throne. Mutual relations between Orodes II, the ruler of Parthia, and Artavasdes II, became closer shortly after the latter came to power, influenced by news of the war against the Parthians planned by M. Licinius Crassus. The prospect of Roman aggression led Orodes II to seek support from the ruler of Armenia. The agreement between the two monarchs was founded on Artavasdes' daughter's marriage to Pacorus, son of Orodes II. ${ }^{44}$ The connection between these events is demonstrated by the fact that the marriage took place during the expedition of the Roman commander. According to Plutarch, Crassus' head was handed to Orodes during a play performed in honour of the wedding ceremony. ${ }^{45}$

This marriage is the last known example of dynastic unions between the Arsacids and the Artaxiads.

\section{c) Dynastic marriages of the Arsacids with other ruling houses}

Apart from marriages with members of the Seleucid and Artaxiad dynasties, the Arsacids also entered into unions with the ruling houses of other neighbouring states. References have survived which indicate that they allied themselves with the rulers of Commagene and Media Atropatene. In the former case, the mutual close relations were cemented by Orodes II's marriage to Laodice, daughter of Antiochus I Theos, king of Commagene. ${ }^{46}$ Similarly to the aforementioned marriage of Pacorus to the daughter of Artavasdes II, this too took place as part of an alliance in response to the aggression of Crassus. The matrimonial activity of the Parthian king shows that he treated familial relations with the kings of Armenia and Commagene as components of the coalition he had constructed against the Roman aggressor. In his son-in-law's hour of need, however, the ruler of Commagene was reluctant to come to his aid in fighting not only Crassus, but also other Roman commanders. ${ }^{47}$ Yet Antiochus I's cautious approach did not lead to a worsening in his relations with Orodes II. The numerous alliances between the king of Commagene and other dynasties meant that marriage to his daughter brought the Parthian king into an extensive network of links between many dynasties. However, Laodice's excellent connections became the cause of a family drama in the Parthian court. Fearing

${ }^{43}$ Plut. Pomp. 33.6; Dio Cassius 37.5.2-6.

${ }^{44}$ Plut. Crass. 33.1.

${ }^{45}$ Plut. Crass. 33.2-4; Debevoise 1938, 92-93.

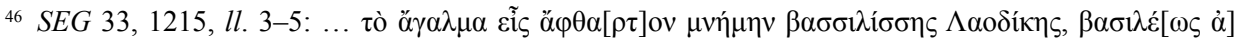

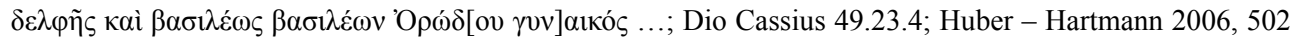
and note 60.

${ }^{47}$ Cf. Sullivan 1978b, 766-770. 
for his position, Phraates IV, the son and heir to Orodes II, murdered his stepbrothers Laodice's sons - partly because their lineage was superior to his own. ${ }^{48}$

All we know about the dynastic connections with the Atropatids, the ruling house in Media Atropatene, is that they took place. The rather vague mention by Strabo does not contain any names either of the rulers of Media Atropatene or of the Parthians during whose rule marriages between the members of the two dynasties occurred. From its context, however, we can conclude that there may even have been a few such marriages over time. ${ }^{49}$ It was by no means by chance that the Arsacids showed interest in familial relations with the kings of the somewhat distant Media Atropatene. As a result of its location between Armenia and Parthia and the military potential it possessed, its rulers were a desirable ally for the Arsacids. ${ }^{50}$

The dynastic marriages of the Arsacids mentioned above include only those which, for various reasons, are referred to in sources. Given the fact that the individual rulers of the dynasty indicated their interest through this form of connections with other ruling houses, and that many of them possessed several wives each and numerous offspring, we can assume that the actual list of dynastic marriages entered into by the Arsacids was much longer. Any digressions on this topic are pure conjecture, however.

There is no doubt that all the dynastic marriages that we know of resulted from the parties' pursuit of either short-term or long-term political objectives. As a result of these unions, acting as a seal on political deals, they hoped to gain the ability to affect their partner's internal affairs, obtain their support in defence against common threats, or bring them closer. Examples of such strategies are both the relations of the Artaxiad dynasty, which reigned Armenia, and the Atropatids, in Media Atropatene. Their marriages to the Seleucids were different. These permitted the Parthian kings to exert influence on the internal policy of the rulers of Syria by interfering in dynastic conflicts. As a result, they were able to force them to soften their aggressive policy towards the Parthian empire. As far as we can ascertain, they managed this only to a limited extent. Perhaps the ineffectiveness of this tool led the Arsacids to cease using it. However, a more likely explanation for their failure to resume attempts to enter into dynastic marriages with the Seleucids after the rule of Mithridates I and Phraates II was the weakness of the latter. Owing to continuing conflicts over the throne among the numerous pretenders, plunging Syria into ever greater political chaos, the Seleucids no longer represented such a threat to the Arsacids for matrimonial unions to be required to blunt it.

The sources suggest that the majority of dynastic marriages were the result of agreements between the respective parties. These certainly included the unions of the Arsacids with the ruling houses of Armenia, Media Atropatene and Commagene. In the case of marriages with the members of the Seleucid dynasty, the situation was completely different - these occurred not as a result of bilateral agreement, but in conditions of coercion. Yet there is no doubt that these marriages were dynastic in nature. For the Arsacids, these unions could potentially be equally useful as marital agreements with other ruling houses, since they made it possible to blackmail the Seleucids with the threat of direct interference in their internal affairs.

\footnotetext{
48 Plut. Crass. 33.5; Just. 42.4.14-43.5.1; Dio Cassius 49.23.3-5.

49 Strabo 11.13.1 (C 523). Cf. Sullivan 1978c, 918; Huber - Hartmann 2006, 502 and note 61.

${ }^{50}$ Cf. Strabo 11.13.1-4 (C 523-524).
} 
Each of the dynastic marriages which the Arsacids entered into of course had its own individual characteristics determined by the circumstances and the time. But there is also no doubt that the Arsacids treated all these unions pragmatically, as a tool for realising both the short-term and the more far-reaching objectives of their imperial policy, mostly in the context of actions undertaken to protect the western boundaries of their state from the aggression of the Seleucids and Rome. We can assume with a large amount of certainty that they also acted similarly to guarantee their interests along the eastern and northern sections of their empire's borders. ${ }^{51}$

BIBLIOGRAPHY

Assar, G.F. (2004), Genealogy and Coinage of the Early Parthian Rulers - I, Parthica 6: 69-93.

Assar, G.F. (2005), Genealogy and Coinage of the Early Parthian Rulers - II: A Revised Stemma, Parthica 7: 29-63.

Assar, G.F. (2006a), A Revised Parthian Chronology of the Period 91-55 BC, Parthica 8: 55-104.

Assar, G.F. (2006b), A Revised Parthian Chronology of the Period 161-91 BC, Electrum 11: 87-158.

Bigwood, J.M. (2008), Some Parthian Queens in Greek and Babylonian Documents, Iranica Antiqua 43: 235-273.

Bouché-Leclercq, A. (1913/1914), Histoire des Séleucides (323-64 avant J.-C.), vol. 1 (1913); vol. 2 (1914), Paris.

Chaumont, M.-L. (1985/1988), À propos des premières interventions parthes en Arménie et des circonstances de l'avènement de Tigrane le Grand, AAAHung 31: 13-25.

Dąbrowa, E. (1983), La politique de l'Etat parthe à l'égard de Rome-d'Artaban II à Vologèse I (ca 11ca 79 de n.e.) - et les facteurs qui la conditionnaient, Kraków.

Dąbrowa, E. (1992), Könige Syriens in der Gefangenschaft der Parther. Zwei Episoden aus der Geschichte der Beziehungen der Seleukiden zu den Arsakiden, Tyche 7: 45-54.

Dąbrowa, E. (2011), Studia Graeco-Parthica: Political and Cultural Relations between Greeks and Parthians, Wiesbaden.

Dąbrowa, E. (2015), L'Histoire des Parthes dans la Géographie de Strabon, Studi Ellenistici 29: 285-303.

Debevoise, N.C. (1938), A Political History of Parthia, Chicago, Il.

Del Monte, G.F. (1997), Testi della Babilonia Ellenistica, vol. 1: Testi cronografici, Pisa-Roma.

Edelstein, L., Kidd, I.G. (1988), Posidonius, vol. 2: The Commentary, part I: Testimonia and Fragments 1-149, Cambridge.

Edelstein, L., Kidd, I.G. (1989), Posidonius, vol. 1: The Fragments, $2^{\text {nd }}$ ed., Cambridge.

${ }^{51}$ The Greek and Roman authors perceive everything regarding the history of the Arsacid state and its internal affairs almost exclusively from the point of view of their conflicts with the Seleucids and Rome. Owing to our extremely limited understanding of the activity of the Parthian rulers in the other regions of their state, any conclusions we form on their objectives and methods used in relation to their neighbours are mostly confined to the western peripheries of their state. The references to the Parthians in Oriental and Chinese sources, although they provide additional information about the past of their state, do not contain any information regarding the Arsacids' dynastic links with their eastern neighbours; cf. Posch 1998. The fact that the Arsacids were able to marry the vassal rulers in the northern reaches of their state might be proven by the fortunes of Artabanus II (Tac. Ann. 2.3.1; 6.42.3), cf. Huber - Hartmann 2006, 502 and note 62. 
Ehling, K. (1998a), Probleme der seleukidischen Chronologie und Geschichte der Jahre zwischen 139 und 131 v.Chr., in: U. Peter (ed.), Stephanos nomismatikos. Edith Schönert-Geiss zum 65. Geburtstag, Berlin: 227-241.

Ehling, K. (1998b), Seleukidische Geschichte zwischen 130-121 v.Chr., Historia 46: 141-151.

Ehling, K. (2008), Untersuchungen zur Geschichte der späten Seleukiden (164-63 v.Chr.). Vom Tode des Antiochos IV. bis zur Einrichtung der Provinz Syria unter Pompeius, Stuttgart.

Fischer, Th. (1970), Untersuchungen zum Partherkrieg Antiochos' VII im Rahmen der Seleukidengeschichte, Tübingen.

Geller, M., Traina, G. (2013), "Tigranu, the Crown Prince of Armenia”: Evidence from the Babylonian Astronomical Diaries, Klio 95: 447-454.

Hackl, U., Jacobs, B., Weber, D. (eds.) (2010), Quellen zur Geschichte des Partherreiches. Textsammlung mit Übersetzungen und Kommentaren, 3 vols., Göttingen-Oakville, CT.

Huber, I., Hartmann, U. (2006), ,Denn ihrem Diktat vermochte der König nicht zu widersprechen... Die Position der Frauen am Hof der Arsakiden, in: A. Panaino, A. Piras (eds.), Proceedings of the $5^{\text {th }}$ Conference of the Societas Iranologica Europea Held in Ravenna, 6-11 October 2003, vol. 1: Ancient and Middle Iranian Studies, Milano: 485-517.

Kovacs, F.L. (2016), Armenian Coinage in the Classical Period, Lancaster, PA-London.

Le Rider, G. (1965), Suse sous les Séleucides et les Parthes. Les trouvailles monétaires et l'histoire de la ville, Paris.

Luther, A. (2018), Zu den Dokumenten aus Avroman, Gymnasium 125: 155-177.

Minns, E.H. (1915), Parchments of the Parthian Period from Avroman in Kurdistan, JHS 35: 22-65.

Mittag, P.F. (2002), Beim Barte des Demetrios. Überlegungen zur parthischen Gefangenschaft Demetrios' II., Klio 84: 373-399.

Nabel, J. (2017), The Seleucids Imprisoned: Arsacid-Roman Hostage Submission and Its Hellenistic Precedents, in: J.M. Schlude, B.B. Rubin (eds.), Arsacids, Romans, and Local Elites: Cross-Cultural Interactions of the Parthian Empire, Oxford-Philadelphia: 25-50.

Posch, W. (1998), Chinesische Quellen zu den Parthern, in: J. Wiesehöfer (ed.), Das Partherreich und seine Zeugnisse / The Arsacid Empire: Sources and Documentation. Beiträge des Internationalen Colloquiums, Eutin (27.-30. Juni 1996), Stuttgart: 355-364.

Sachs, A., Hunger, H. (1996), Astronomical Diaries and Related Texts from Babylonia, vol. III: Diaries from 164 B.C. to 61 B.C., Wien.

Seibert, J. (1967), Historische Beiträge zu den dynastischen Verbindungen in hellenistischer Zeit, Wiesbaden.

Shayegan, M.R. (2003), On Demetrius II Nicator's Arsacid Captivity and Second Rule, Bulletin of the Asia Institute 17: 83-103.

Strugnell, E. (2008), Thea Musa, Roman Queen of Parthia, Iranica Antiqua 43: 275-298.

Sullivan, R.D. (1978a), The Dynasty of Emesa, $A N R W$ II, 8: 198-219.

Sullivan, R.D. (1978b), The Dynasty of Commagene, $A N R W$ II, 8: 732-798.

Sullivan, R.D. (1978c), Papyri Reflecting the Eastern Dynastic Network, $A N R W$ II, 8: 908-939.

Will, E. (1982), Histoire politique du monde hellénistique (323-30 av. J.-C.), $2^{\text {nd }}$ ed., vol. 2, Nancy.

Wolski, J. (1980), L'Arménie dans la politique du Haut-Empire parthe (env. 175-87 av. n.è.), Iranica Antiqua 15: 251-267. 